\title{
WSI
}

Diskussionspapiere

\section{Interest rate, debt, distribution and capital accumulation in a post-Kaleckian model}

\author{
Eckhard Hein
}

WSI Discussion Paper No. 133

December 2004

Wirtschafts- und Sozialwissenschaftliches Institut in der Hans-Böckler-Stiftung, Düsseldorf 
Eckhard Hein

WSI in der Hans Boeckler Stiftung

Hans Boeckler Str. 39

40476 Duesseldorf

Germany

eckhard-hein@boeckler.de

This paper and further WSI Discussion Papers can be downloaded from: www.wsi.de. 


\title{
WSI
}

Diskussionspapiere

\section{Interest rate, debt, distribution and capital accumulation in a post-Kaleckian model}

\author{
Eckhard Hein
}

WSI Discussion Paper No. 133

December 2004

Wirtschafts- und Sozialwissenschaftliches Institut in der Hans-Böckler-Stiftung, Düsseldorf 


\title{
Interest rate, debt, distribution and capital accumulation in a post-Kaleckian model ${ }^{*}$
}

\author{
Eckhard Hein
}

\begin{abstract}
The introduction of monetary variables into post-Keynesian models of distribution and growth is an ongoing process. Lavoie (1995) has proposed a Kaleckian 'Minsky-Steindlmodel' of distribution and growth, incorporating the effects debt and debt services have on short and long run capital accumulation. This attempt, however, can be extended because neither has the rate of capacity utilisation been endogenously determined, nor have the potential effects of interest rate variations on distribution between wages and gross profits explicitly been incorporated in the model. In the present paper we therefore augment Lavoie's 'Minsky-Steindl-model', building our analysis on a Kaleckian distribution and growth model which has already taken into account distribution effects of interest rate variations on the short run equilibrium. Into this model the effects of debt and debt services are explicitly introduced, the effects of interest rate variations on the short and the long run equilibrium are derived, and the results are compared to those of Lavoie's 'Minsky-Steindl-model'. It is shown, that the effects of interest variations on the endogenously determined equilibrium values of the model do not only depend on the parameter values in the savings and investment functions but also on initial conditions with respect to the interest rate and the debt-capital-ratio.
\end{abstract}

JEL-classification: E12, E22, E25, E44, O42

Keywords: Interest rate, debt, distribution, capital accumulation

\footnotetext{
* The paper has been presented at the 8th Workshop of the Research Network 'Alternative Conceptions of Macroeconomic Policies under the Conditions of Unemployment, Globalisation and High Public Debt' on 'Wages, Distribution and Growth', Berlin, 29 - 30 October, 2004. For helpful comments I would like to thank the conference participants and especially Andranik Tangian and Achim Truger. Remaining errors are, of course, mine.
} 


\section{Introduction}

Until recently, the impacts of monetary variables have rarely been considered to be relevant for the equilibrium solution in post-Keynesian models of distribution and growth in the tradition of Kaldor $(1956,1957,1961)$ and Robinson (1962), on the one hand, and Kalecki (1954) as well as Steindl (1952), on the other hand. ${ }^{1}$ In the 1980s/90s, however, postKeynesians have started to take Keynes's (1933) research programme of a 'monetary theory of production' seriously and have introduced monetary variables into the Kaldorian and Kaleckian variants of the post-Keynesian growth and distribution models. ${ }^{2}$ These models usually rely upon the post-Keynesian 'horizontalist' approach to monetary theory: The rate of interest is considered to be an exogenous variable for production and accumulation mainly under the control of the central bank whereas the quantities of credit and money are endogenous to production and accumulation. ${ }^{3}$ Integrating this approach into post-Keynesian models of distribution and growth has meant to integrate the rate of interest explicitly into the investment function, in the first place. Lavoie (1995) has shown the results for the basic Kaldorian/Robinsonian and Kaleckian models: Rising interest rates will be associated with lower rates of capital accumulation in both types of models. In the Kaleckian models with a long run variable rate of capacity utilisation, the equilibrium rate of utilisation will fall when interest rates rise, whereas income distribution determined by mark-up pricing will remain constant. In the Kaldorian/Robinsonian model, however, with a long run normal rate of capacity utilisation and distribution determined by capital accumulation, rising interest rates will be associated with a falling profit share and a decreasing 'normal' rate of profit. ${ }^{4}$

\footnotetext{
${ }^{1}$ See Amadeo (1986, 1986a, 1987), Bhaduri/Marglin (1990), Dutt (1984, 1987), Kurz (1994, 1995) and Rowthorn (1981) for modern Kaleckian models, and Lavoie (1992, pp. 282-347) as well as Hein (2004, pp. 149219) for surveys of Kaldorian/Robinsonian and Kaleckian models of distribution and growth.

${ }^{2}$ See, among others, in particular Lavoie (1992, pp. 347-371, 1993, 1995), Lavoie/Rodriguez/Seccareccia (2004), Dutt/Amadeo (1993), Dutt (1989, 1992), Taylor (1985) and Hein (1999, 2004, pp. 221-238). Hein/Ochsen (2003) have used a Kaleckian type model in order to assess the empirical development of interest rates, income shares and capital accumulation in some advanced OECD countries. The introduction of monetary variables into the models based on Robinson and Kalecki has solid foundation in the work of these authors. See Lavoie (1999), Rochon (1999, pp. 143-150, 2001), Vernengo/Rochon (2001) on Joan Robinson, and Arestis (1996), Dymski (1996) and Sawyer (1985, pp. 88-107, 2001, 2001a) on Michal Kalecki. And, of course, Kaldor $(1970,1982,1985)$ has been the founding father of the post-Keynesian 'horizontalist' theory of money (see also Rochon (1999, pp. 99-117, 2000) and Vernengo/Rochon (2001)).

${ }^{3}$ See Kaldor (1970, 1982, 1985), Lavoie (1984, 1992, pp. 149-216, 1996), Moore $(1988,1989)$ and Rochon (1999) for the post-Keynesian 'horizontalist' approach to monetary theory.

${ }^{4}$ Lavoie (1995) shows that this result is not only true for the Kaldor/Robinson variant of the post-Keynesian distribution and growth model based on flexible prices with respect to demand but also for Eichner's model based on mark-up pricing in oligopolistic goods market in which the mark-up is determined by the required internal means of finance for planned investment.
} 
The introduction of monetary variables into post-Keynesian models of distribution and growth, however, cannot be confined to only having directly adverse effects on capital accumulation. Changing interest rates also mean a redistribution of income between rentiers and firms with related effects on aggregate savings and consumption demand. And lasting variations in interest rates may also affect functional income distribution and hence the share of wages and gross profits in total income, as has been proposed by neo-Ricardian authors and can as well be found in Joan Robinson's work (Lavoie (1995)). ${ }^{5}$ Integrating these effects into post-Keynesian models of distribution and growth makes the effects of changing interest rates dependent on the parameter values in the investment and the savings functions and on the elasticity of distribution with respect to interest rate variations. For a Kaleckian model, different regimes of accumulation can be derived, ranging from the usually expected adverse effects of interest rate variations on capital accumulation, capacity utilisation and the profit rate to positive effects throughout on the equilibrium values of the system (Lavoie (1993, 1995), Hein (1999), Hein/Ochsen (2003)).

However, also these models should only be considered a further step towards a better understanding of the short and long run effects of monetary variables on distribution and growth, because the effects of debt and debt services which have been highlighted by Kalecki (1937, 1954), Steindl (1952) and Minsky (1975) have not yet been fully incorporated. Lavoie (1995) proposes an attempt to introduce these aspects into a Kaleckian 'Minsky-Steindlmodel' of distribution and growth. His attempt, however, can be extended because he does not endogenously determine the rate of capacity utilisation and simply assumes it to be constant. Lavoie's model also does not consider a potential effect of interest rate variations on the distribution of income between wages and gross profits in the savings and investment function. Therefore, in what follows we will augment Lavoie's 'Minsky-Steindl-model' and address some of these effects. In order to do this we will base our analysis on the model briefly outlined by Lavoie (1993) and further elaborated in Hein (1999) and explicitly consider the effects of debt and interest payments in this model, in the short as well as in the long run. The remainder of the paper is organised as follows. In Section 2 we will describe the basic assumptions and the main characteristics of our model. Section 3 derives the short run equilibrium and Section 4 the equilibrium in the long run. In Section 5 we discuss the effects

\footnotetext{
${ }^{5}$ See Ciccarone (1998), Panico (1985) and Pivetti (1985, 1987, 1991, 2001), among others.
} 
variations in the interest rate have on the short and long run behaviour of a simple variant of our model. Section 6 concludes.

\section{The basic model}

In our model we assume a closed economy without economic activity of the state. Technical change is not explicitly considered. Under given conditions of production, there is just one type of commodity produced that can be used for consumption and investment purposes. It is assumed that there is a constant relation between the employed volume of labour (L) and real output (Y), i.e. there is no overhead-labour. The productivity of labour is therefore constant up to full capacity output and we get a constant labour-output-ratio (l). The capital-potential output-ratio (v) which describes the relation between the real capital stock (K) and potential real output $\left(\mathrm{Y}^{v}\right)$ is also supposed to be constant. The capital stock is assumed not to depreciate. The rate of capacity utilisation $(\mathrm{u})$ is given by the relation between actual real output and potential real output.

Functional income distribution is determined by active price setting of firms in incompletely competitive goods markets. Writing $\mathrm{w}$ for the nominal wage rate, we assume that firms set prices (p) according to a mark-up (m) on constant unit labour costs up to full capacity output. Following Kalecki (1954, pp. 11-27), we assume that the mark-up in the price equation is mainly determined by the degree of price competition in the goods markets and by the relative powers of capital and labour in the labour market:

$$
\mathrm{p}=(1+\mathrm{m}) \mathrm{wl}, \quad \mathrm{m}>0 .
$$

From this we get for the profit share (h), i.e. the proportion of profits $(\Pi)$ in nominal output $(\mathrm{pY})$ :

$$
\mathrm{h}=\frac{\Pi}{\mathrm{pY}}=1-\frac{1}{1+\mathrm{m}} .
$$

The profit rate $\mathrm{r}$ relates the annual flow of profits to the nominal capital stock. The rate of profit depends on the endogenously determined profit share, the rate of capacity utilisation and the capital-potential output-ratio: 


$$
\mathrm{r}=\frac{\Pi}{\mathrm{pK}}=\frac{\Pi}{\mathrm{Y}} \frac{\mathrm{Y}}{\mathrm{Y}^{\mathrm{v}}} \frac{\mathrm{Y}^{\mathrm{v}}}{\mathrm{K}}=\mathrm{hu} \frac{1}{\mathrm{v}}
$$

Introducing monetary variables into the model, we follow the post-Keynesian 'horizontalist' monetary view developed by Kaldor (1970, 1980, 1982), Lavoie (1984, 1992, pp. 149-216, 1996) and Moore $(1988,1989)$ and assume that the monetary interest rate is an exogenous variable for the accumulation process whereas the quantities of credit and money are determined endogenously by economic activity. In this view, the central bank controls the base rate of interest. Commercial banks set the market rate of interest by marking up the base rate and then supply the credit demand of consumers and investors they consider creditworthy at this interest rate. The central bank accommodates the necessary amount of cash. For the sake of simplicity, in what follows we suppose that the central bank's interest rate policy controls the real long-term interest rate, i.e. the long-term nominal interest rate corrected by the inflation rate. The pace of capital accumulation therefore has no direct feedback on the interest rate. The position taken here in so far differs from those post-Keynesian views which assume that a decreasing liquidity position of commercial banks and rising lender's and borrower's risk finally lead to rising interest rates when the volume of credit is expanding in the accumulation process (Minsky (1986), Palley (1996), Rousseas (1998), Wray (1990)). In our post-Keynesian distribution and growth model based on the principle of effective demand, we rather follow Pasinetti's recommendation for the treatment of the rate of interest in the theory of effective demand:

„However important a role liquidity preference may play in Keynes’ monetary theory, it is entirely immaterial to his theory of effective demand. What this theory requires, as far as the rate of interest is concerned, is not that the rate of interest is determined by liquidity preference, but that it is determined exogenously with respect to the income generation process. Whether, in particular, liquidity preference, or anything else determines it, is entirely immaterial." (Pasinetti (1974, p. 47))

The pace of accumulation is determined by the entrepreneurs' decisions to invest. But investment as the causal force of accumulation has to be financed independently of savings, because investment precedes income and hence savings. Therefore, firms need access to 
credit. Short-term credit is needed for 'finance' or 'initial finance' of additional production. ${ }^{6}$ The banking sector is capable of supplying any creditworthy demand for credit at a given interest rate determined by the policies of the central bank. The supply of short-term credit is therefore not limited by the supply of savings. When production has been initiated and income has been generated, the proportion of income not consumed, i.e. savings, stands ready to supply the 'final finance' or 'funding' of investment goods newly produced. In general, this may take place through retained earnings, the issuing of bonds and shares or through longterm credit. Here we shall assume that funding is supplied only by retained earnings or by long-term credit of rentiers' households. By means of this simplification we do not have to distinguish between creditor households receiving interest income, on the one hand, and shareholder households receiving dividend income, on the other hand, and their different savings propensities, as in Lavoie (1995). ${ }^{7}$

We further assume that the monetary circuit will be closed in each period. This means there is no varying demand for liquidity by private households which could disturb the transformation of short-term credit into long-term credit or the conversion of 'initial finance' into 'final finance'. Under these conditions, we may also assume a single interest rate determined by the policy of the central bank.

Introducing interest payments to rentiers' households into the model, profit splits into profit of enterprise $\Pi^{\mathrm{n}}$ and rentiers ${ }^{6}$ income $\mathrm{Z}^{8}{ }^{\text {Rentiers }}{ }^{6}$ income is determined by the stock of longterm credit $\mathrm{B}$ granted to firms and the exogenously given rate of interest $\mathrm{i}$.

$$
\Pi=\Pi^{\mathrm{n}}+\mathrm{Z}=\Pi^{\mathrm{n}}+\mathrm{iB} .
$$

The debt-capital-ratio is denoted by $\lambda$. This ratio is assumed to be given in the short run but it will vary in the long run:

\footnotetext{
${ }^{6}$ The distinction between short term finance for production purposes and long-term finance for investment purposes can be found in the monetary circuit approach (see, in particular, Graziani (1989, 1994), Lavoie (1992, pp. 151-169), Seccareccia (1996, 2003)).

${ }^{7}$ Of course, our simplification implies that the propensity to save of capital owners and shareholders is unity.

${ }^{8}$ In what follows the terms 'profit', 'profit share' and 'profit rate' are related to gross profits as the sum of profit of enterprise and interest.
} 


$$
\lambda=\frac{\mathrm{B}}{\mathrm{pK}} .
$$

The mark-up and the profit share also consist of two parts when interest is introduced, a part that covers profits of enterprise and a part for interest payments. According to Kalecki (1954, p. 18), the degree of monopoly, and hence the mark-up, may but need not increase when overhead costs, including interest costs, increase. Therefore, the profit share may but need not respond to a variation in the interest rate:

$$
\mathrm{h}=\mathrm{h}(\mathrm{i}), \quad \frac{\partial \mathrm{h}}{\partial \mathrm{i}} \geq 0 .
$$

Considering the distribution effects of interest rate variations we will consider two cases: 1 . the case of an interest-inelastic or rigid mark-up and 2. the case of an interest-elastic or flexible mark-up. If an interest-inelastic mark-up prevails the real wage will not be affected by interest rate variations. Changing interest rates do not affect the distribution of income between wages and profits but only cause a redistribution between profits of enterprise and rentiers' income. This view can be found in Marx's theory of interest that considers interest payments a part of surplus value produced by productive labourers (Marx (1967, pp. 338)). ${ }^{9}$ If an interest-elastic mark-up dominates, changing interest rates will directly affect the real wage. Rising (falling) interest rates cause rising (falling) mark-ups, rising (falling) prices, and falling (rising) real wages at constant nominal wages. Under these conditions, changing interest rates affect the distribution of income between profits and wages, whereas the profits of enterprise remain constant. This position that considers interest a part of firms' costs of production can be found in neo-Ricardian work (Panico (1985), Pivetti $(1985,1988,1991)$ ). There it is assumed that the exogenously given interest rate determines the rate of profit and closes the degree of freedom of the production price model by Sraffa (1960). ${ }^{10}$

As the successful shifting of variations in interest rates to prices means a change in the markup, the ability to enforce a permanent and stable redistribution of income at the expense of labour income by shifting interest rate changes to prices depends on those factors that

\footnotetext{
${ }^{9}$ See also Pivetti (1987) and Hein (2004a, 2006).

10 "The rate of profits, as a ratio, has a significance which is independent of any prices, and can well be 'given' before the prices are fixed. It is accordingly susceptible of being determined from outside the system of production, in particular by the level of the money rates of interest." (Sraffa $(1960$, p. 33))
} 
determine the mark-up, i.e. the intensity of price competition in the goods market and the relative strength of labour unions in the labour market. We may expect that a high intensity of competition and strong unions prevent rising interest rates from being shifted to higher prices permanently, but enforce falling interest rates to be transferred to falling prices. If the intensity of competition is rather low and unions are rather weak, rising interest rates will probably be accompanied by rising prices, whereas falling interest rates will not lead to falling prices.

Introducing the interest rate into the savings and accumulation function of the model the following aspects have to be considered. First, interest payments by firms are an income for rentiers' households that will affect those households' expenditures and thus consumption demand and the rate of capacity utilisation. Second, in the case of a flexible mark-up interest rate variations have an impact on real wages and hence on the wage-costs of production, but also on consumption demand out of wages. Third, interest payments are costs for firms and a drain of their internal means of finance which will directly affect their decisions to accumulate.

In order to keep the argument simple, we will assume a classical savings hypothesis, i.e. labourers do not save. The part of profits retained is completely saved by definition. The part of profits distributed to rentiers' ${ }^{6}$ households, i.e. the interest payment, is used by those households according to their propensity to save $\left(\mathrm{s}_{\mathrm{Z}}\right)$ for consumption and savings $\left(\mathrm{S}_{\mathrm{Z}}\right)$. Therefore, total savings (S) comprise retained profits and savings out of interest income. Taking equations (3), (4) and (5) into account, for the savings rate $(\sigma)$ which relates total savings to the nominal capital stock we get:

$$
\sigma=\frac{\mathrm{S}}{\mathrm{pK}}=\frac{\Pi-\mathrm{Z}+\mathrm{S}_{\mathrm{Z}}}{\mathrm{pK}}=\mathrm{h} \frac{\mathrm{u}}{\mathrm{v}}-\mathrm{i} \lambda\left(1-\mathrm{s}_{\mathrm{Z}}\right), \quad 0<\mathrm{s}_{\mathrm{Z}} \leq 1
$$

The higher the interest rate at a given rate of profit, a given debt-capital-ratio and a given propensity to save of rentiers' households the lower will be the savings rate, because income is transferred from firms that do not consume to rentiers who consume at least a part of their income. An increasing debt-capital-ratio reduces the savings rate for the same reason. 
For the accumulation function, we rely on a monetary extension of the function proposed by Bhaduri/Marglin (1990). In their non-monetary model based on the principle of effective demand, the decisions to invest are assumed to depend on the rate of profit. Assuming the technical conditions of production to be constant, the profit rate is decomposed into the profit share reflecting the development of unit costs and the rate of capacity utilisation indicating the development of demand. Firms now have to at least partially finance their net investment spending by credit. Following Kalecki's (1937) 'principle of increasing risk' we shall assume that the firms access to credit is positively correlated with the firms' internal means of finance and negatively with their debt-capital-ratios:

"The access of a firm to the capital market, or in other words the amount of rentier capital it may hope to obtain, is determined to a large extent by the amount of its entrepreneurial capital." (Kalecki (1954, p. 91))

The higher the amount of the firms' own capital, the higher the amount of debt capital that can be obtained for investment. ${ }^{11}$ Contrary to his earlier writing in Kalecki (1937), in Kalecki (1954, p. 91-92) the willingness of the firm to pay higher interest rates cannot compensate for a lack of internal funds or entrepreneurial capital. The firm's willingness to pay higher interest rates rather reinforces the creditors' scepticism with respect to the creditworthiness of the potential debtor. From these arguments it follows, that the rate of interest and the debt-capitalratio have a negative impact on investment. Therefore, a simple linear function for the accumulation rate $\mathrm{g}$ relating net investment $\mathrm{I}$ to the capital stock can be formulated as follows:

$$
\mathrm{g}=\frac{\Delta \mathrm{K}}{\mathrm{K}}=\frac{\mathrm{I}}{\mathrm{K}}=\alpha+\beta \mathrm{u}+\tau \mathrm{h}-\theta \lambda \mathrm{i}, \quad \alpha, \beta, \tau, \theta>0, \quad \mathrm{~g}>0 \text { for } \mathrm{r}-\mathrm{i}>0 .
$$

The parameter $\alpha$ stands for the motivation to accumulate which derives from the competition of firms independently of the development of distribution, effective demand, monetary or financial variables. The intensity of the influence of effective demand is indicated by $\beta$, whereas $\tau$ shows the weight of distribution struggle and $\theta$ the impact of debt and the interest rate. To induce investors to demand real capital goods instead of financial assets, the expected rate of profit has to exceed the rate of interest in financial markets.

\footnotetext{
${ }^{11}$ A similar view was taken by Robinson (1962, p. 86) and Steindl (1952, pp. 107-138). Recent empirical work has shown that the interest rate has important effects on investment through its impacts on internal funds and hence on the access to external borrowing on imperfect capital markets (see Fazzari/Hubbard/Peterson (1988), Hubbard (1998), Schiantarelli (1996)).
} 
In what follows we will derive the short and the long run equilibrium positions of the system. Following Lavoie (1995), we take the debt-capital-ratio as a constant in the short run which, however, becomes a variable to be endogenously determined in the long run.

\section{Short run equilibrium}

The short run equilibrium requires the adjustment of production and capacity utilisation to effective demand in the goods market. Therefore, the equilibrium condition is given by:

$$
g=\sigma
$$

This equilibrium will be stable, if savings respond more elastically to variations in capacity utilisation then investment:

$$
\begin{aligned}
& \frac{\partial \sigma}{\partial \mathrm{u}}-\frac{\partial \mathrm{g}}{\partial \mathrm{u}}>0, \\
& \frac{\mathrm{h}}{\mathrm{v}}-\beta>0 .
\end{aligned}
$$

The equilibrium values $\left(^{*}\right)$ for capacity utilisation, capital accumulation and the rate of profit in the short run are as follows:

$$
\begin{aligned}
& \mathrm{u}^{*}=\frac{\lambda \mathrm{i}\left(1-\mathrm{s}_{\mathrm{Z}}-\theta\right)+\alpha+\tau \mathrm{h}}{\frac{\mathrm{h}}{\mathrm{v}}-\beta}, \\
& \mathrm{g}^{*}=\frac{\lambda \mathrm{i}\left[\beta\left(1-\mathrm{s}_{\mathrm{Z}}\right)-\theta \frac{\mathrm{h}}{\mathrm{v}}\right]+\frac{\mathrm{h}}{\mathrm{v}}(\alpha+\tau \mathrm{h})}{\frac{\mathrm{h}}{\mathrm{v}}-\beta}, \\
& \mathrm{r}^{*}=\frac{\frac{\mathrm{h}}{\mathrm{v}}\left[\lambda \mathrm{i}\left(1-\mathrm{s}_{\mathrm{Z}}-\theta\right)+\alpha+\tau \mathrm{h}\right]}{\frac{\mathrm{h}}{\mathrm{v}}-\beta} .
\end{aligned}
$$


With a constant debt-capital-ratio in the short run, we get the following reactions of the equilibrium values in the face of changing interest rates:

$$
\begin{aligned}
& \frac{\partial \mathrm{u}}{\partial \mathrm{i}}=\frac{\lambda\left(1-\mathrm{s}_{\mathrm{Z}}-\theta\right)+\frac{\partial \mathrm{h}}{\partial \mathrm{i}}\left(\tau-\frac{\mathrm{u}}{\mathrm{v}}\right)}{\frac{\mathrm{h}}{\mathrm{v}}-\beta}, \\
& \frac{\partial \mathrm{g}}{\partial \mathrm{i}}=\frac{\lambda\left[\beta\left(1-\mathrm{s}_{\mathrm{Z}}\right)-\theta \frac{\mathrm{h}}{\mathrm{v}}\right]+\frac{\partial \mathrm{h}}{\partial \mathrm{i}} \frac{1}{\mathrm{v}}(\tau \mathrm{h}-\beta \mathrm{u})}{\frac{\mathrm{h}}{\mathrm{v}}-\beta}, \\
& \frac{\partial \mathrm{r}}{\partial \mathrm{i}}=\frac{\frac{\mathrm{h}}{\mathrm{v}} \lambda\left(1-\mathrm{s}_{\mathrm{Z}}-\theta\right)+\frac{\partial \mathrm{h}}{\partial \mathrm{i}} \frac{1}{\mathrm{v}}(\tau \mathrm{h}-\beta \mathrm{u})}{\frac{\mathrm{h}}{\mathrm{v}}-\beta} .
\end{aligned}
$$

If only stable short run equilibria are considered, the short run effects of interest rate variations depend on the interest rate elasticity of the mark-up (and hence the profit share), on the parameters in the savings and investment functions, i.e. the rentiers' savings propensity and the elasticity of investment with respect to the debt and the interest rate, to the profit share and to capacity utilisation, and may also be affected by the debt-capital-ratio (Table 1).

In the case of a rigid mark-up, the reaction of the equilibrium values to changes in the interest rate is mainly determined by the rentiers' propensity to save and by the debt and the debt service elasticity of investment. If the rentiers' savings propensity is rather high and the debt service elasticity of investment rather high as well, rising interest rates will cause falling rates of capacity utilisation, profit and capital accumulation. This is the 'normal' case usually expected in post-Keynesian models. If investment, however, is hardly affected by debt and debt services and the propensity to save out of interest income is relatively low, there may arise regimes of accumulation with positive responses throughout the endogenously determined equilibrium values. This is what Lavoie (1995) calls the 'puzzling' case. With a rigid mark-up, the debt-capital-ratio does not affect the direction of change of the equilibrium values, but only affects the extent of change: The lower the debt-capital-ratio, the smaller will be the effects of interest rate variations. With a zero debt-capital-ratio and a rigid mark-up, a change in the interest rate will not affect the short run equilibrium position at all, as long as 
the interest rate remains below the profit rate and the restriction in equation (8) is fulfilled. Theses results are similar to Lavoie's (1995).

In the case of an interest-elastic mark-up, not discussed by Lavoie (1995), however, the debtcapital-ratio may affect the direction of change of the equilibrium position caused by an interest rate variation. In general, the lower the debt-capital-ratio is, the lower are the direct effects interest rate variations have on investment and on rentiers' consumption and the more important are the effects exerted by the redistribution of income between profits and wages on consumption and investment. With an increasing mark-up following rising interest rates there will be an indirect positive impact on capacity utilisation, capital accumulation and the profit rate running through distribution, if investment is very elastic with respect to the profit share and very inelastic with respect to capacity utilisation. This may then dampen and perhaps even overcompensate a direct negative impact rising interest rates have on investment, or reinforce a direct positive impact. Therefore, in the case of an interest-elastic mark-up, the debt-capital-ratio may be of utmost importance for the direction into which changes in monetary policy push the economy. 


\begin{tabular}{|c|c|c|c|}
\hline \multicolumn{4}{|c|}{ to a variation in the interest rate: stable short-run equilibria } \\
\hline & $\frac{\partial \mathrm{u}}{\partial \mathrm{i}}$ & $\frac{\partial g}{\partial i}$ & $\frac{\partial \mathrm{r}}{\partial \mathrm{i}}$ \\
\hline$\frac{\partial \mathrm{h}}{\partial \mathrm{i}}=0$ & $\begin{array}{l}\frac{\partial \mathrm{u}}{\partial \mathrm{i}}>0, \text { if } \\
\lambda\left(1-\mathrm{s}_{\mathrm{Z}}-\theta\right)>0\end{array}$ & $\begin{array}{l}\frac{\partial g}{\partial \mathrm{i}}>0, \text { if } \\
\lambda\left[\beta\left(1-\mathrm{s}_{\mathrm{z}}\right)-\theta \frac{\mathrm{h}}{\mathrm{v}}\right]>0\end{array}$ & $\begin{array}{l}\frac{\partial \mathrm{r}}{\partial \mathrm{i}}>0, \text { if } \\
\lambda\left(1-\mathrm{s}_{\mathrm{Z}}-\theta\right)>0\end{array}$ \\
\hline$\frac{\partial \mathrm{h}}{\partial \mathrm{i}}>0$ & $\begin{array}{l}\frac{\partial \mathrm{u}}{\partial \mathrm{i}}>0, \text { if } \\
\lambda\left(1-\mathrm{s}_{\mathrm{z}}-\theta\right)+\frac{\partial \mathrm{h}}{\partial \mathrm{i}}\left(\tau-\frac{\mathrm{u}}{\mathrm{v}}\right)>0\end{array}$ & $\begin{array}{l}\frac{\partial \mathrm{g}}{\partial \mathrm{i}}>0, \text { if } \\
\lambda\left[\beta\left(1-\mathrm{s}_{\mathrm{Z}}\right)-\theta \frac{\mathrm{h}}{\mathrm{v}}\right]+\frac{\partial \mathrm{h}}{\partial \mathrm{i}} \frac{1}{\mathrm{v}}(\tau \mathrm{h}-\beta \mathrm{u})>0\end{array}$ & $\begin{array}{l}\frac{\partial \mathrm{r}}{\partial \mathrm{i}}>0, \text { if } \\
\frac{\mathrm{h}}{\mathrm{v}} \lambda\left(1-\mathrm{s}_{\mathrm{Z}}-\theta\right)+\frac{\partial \mathrm{h}}{\partial \mathrm{i}} \frac{1}{\mathrm{v}}(\tau \mathrm{h}-\beta \mathrm{u})>0\end{array}$ \\
\hline
\end{tabular}




\section{Long run equilibrium}

In the long run, the debt-capital-ratio becomes an endogenous variable which then also has feedback effects on the other variables of the system. In order to analyse this, we start with equation (5) and assume away inflation, i.e. the mark-up may change but not the price level. For the growth rates of the variables it follows:

$$
\hat{\lambda}=\hat{B}-\hat{K}=\hat{B}-g
$$

Given our assumptions above, the additional long-term credit granted in each period $(\Delta \mathrm{B})$ is equal to rentiers' savings in this period. This does not imply that rentiers' savings is a precondition for credit and investment. On the contrary, rentiers' savings - as well as firms' retained earnings - are a result of investment initially financed by short term credit, as has been made clear in monetary circuit theory. ${ }^{12}$

$$
\Delta \mathrm{B}=\mathrm{S}_{\mathrm{Z}}=\mathrm{s}_{\mathrm{Z}} \mathrm{iB}
$$

For the growth rate of debt it follows:

$$
\hat{\mathrm{B}}=\frac{\Delta \mathrm{B}}{\mathrm{B}}=\mathrm{s}_{\mathrm{z}} \mathrm{i}
$$

In long run equilibrium the endogenously determined debt-capital-ratio has to be constant, i.e. $\hat{\lambda}=0$. Integrating this condition into equation (17) and making use of equations (12) and (19) we get for the long run equilibrium debt-capital-ratio:

$$
\lambda *=\frac{\mathrm{s}_{\mathrm{z}} \mathrm{i}\left(\frac{\mathrm{h}}{\mathrm{v}}-\beta\right)-\frac{\mathrm{h}}{\mathrm{v}}(\alpha+\tau \mathrm{h})}{\mathrm{i}\left[\beta\left(1-\mathrm{s}_{\mathrm{z}}\right)-\theta \frac{\mathrm{h}}{\mathrm{v}}\right]} .
$$

\footnotetext{
${ }^{12}$ See again Graziani (1989, 1996), Lavoie (1992, pp. 151-169) and Seccareccia (1996, 2003).
} 
This equilibrium will be stable, if $\frac{\partial \hat{\lambda}}{\partial \lambda}<0$ (Lavoie (1995, p. 168)). Making use of equation (17) and applying equations (12) and (19) yields:

$$
\frac{\partial \hat{\lambda}}{\partial \lambda}=\frac{-i\left[\beta\left(1-s_{z}\right)-\theta \frac{h}{v}\right]}{\frac{h}{v}-\beta}
$$

From this it follows for the stability condition: ${ }^{13}$

$$
\frac{\partial \hat{\lambda}}{\partial \lambda}<0, \text { if }: \beta\left(1-s_{z}\right)-\theta \frac{h}{v}>0
$$

The long run equilibrium tends to be stable, if the rentiers' savings propensity is low and investment decisions are very elastic with respect to changes in capacity utilisation but very inelastic with respect to changes in debt services. As in Lavoie (1995), this is the same parameter constellation which favours a 'puzzling' positive effect of interest rate increases on capacity utilisation, capital accumulation and the profit rate in the short run. If the rentiers' savings propensity is rather high and investment decisions are very inelastic with respect to demand but very elastic with respect to debt and debt services, the long run equilibrium tends to become unstable. Deviations from equilibrium will generate a long run debt-capital-ratio of either unity or zero. The conditions for long run instability are associated with short run 'normal' negative effects of interest rate hikes on capacity utilisation, capital accumulation and the profit rate.

The effects of interest rate variations on the equilibrium debt-capital-ratio can be derived from equation (20):

$$
\frac{\partial \lambda}{\partial i}=\frac{s_{Z}\left(\frac{h}{v}-\beta\right)-\lambda\left[\beta\left(1-s_{z}\right)-\theta \frac{h}{v}\right]+\frac{\partial h}{\partial i} \frac{1}{v}\left[i\left(s_{z}+\theta \lambda\right)-\alpha-2 \tau h\right]}{i\left[\beta\left(1-s_{Z}\right)-\theta \frac{h}{v}\right]} .
$$

\footnotetext{
${ }^{13}$ Note, that the stability of the goods market equilibrium implies (h/v)- $\beta>0$.
} 
First we consider the case of an interest-inelastic mark-up. With the conditions for a stable long run equilibrium given, increasing interest rates will decrease the equilibrium debtcapital-ratio if this ratio is very high in the initial equilibrium, more precisely when $\lambda>\frac{s_{z}\left(\frac{h}{v}-\beta\right)}{\beta\left(1-s_{z}\right)-\theta \frac{h}{v}}($ Appendix A). However, if interest rates increase when the equilibrium debt-capital-ratio is still low, i.e. $\lambda<\frac{s_{z}\left(\frac{h}{v}-\beta\right)}{\beta\left(1-s_{z}\right)-\theta \frac{h}{v}}$, this ratio will be rising. When $\lambda=\frac{\mathrm{s}_{\mathrm{Z}}\left(\frac{\mathrm{h}}{\mathrm{v}}-\beta\right)}{\beta\left(1-\mathrm{s}_{\mathrm{Z}}\right)-\theta \frac{\mathrm{h}}{\mathrm{v}}}$ in the initial equilibrium, variations in the interest rate will not affect the equilibrium debt-capital-ratio. These results are different from Lavoie's (1995) who gets a uniquely positive relation between the interest rate and the debt-capital-ratio in the case of a stable long run equilibrium. If the parameter constellation in our model implies an unstable long run equilibrium, rising interest rates will always trigger falling equilibrium debt-capitalratios (Appendix B), as in Lavoie (1995).

In the case of an interest-elastic mark-up - not discussed by Lavoie (1995) -, our results are slightly modified. When the conditions for a stable long run equilibrium are given, a positive relation between the interest rate and the debt-capital-ratio becomes more likely, if investment decisions are quite inelastic with respect to unit labour costs and if in the initial equilibrium the interest rate is already very high, so that $i\left(s_{z}+\theta \lambda\right)-\alpha-2 \tau h>0$. With a high elasticity of investment with respect to unit labour costs and a low interest rate in the initial equilibrium, i.e. $\mathrm{i}\left(\mathrm{s}_{\mathrm{Z}}+\theta \lambda\right)-\alpha-2 \tau \mathrm{h}<0$, an interest-elastic mark-up will make a negative relation between the interest rate and the debt-capital-ratio more likely. If the long run equilibrium is unstable, a low unit labour cost elasticity of investment and a high interest rate in initial equilibrium will reinforce the negative relation between the interest rate and the debt-capital-ratio. If the unit labour cost elasticity of investment is very high and increasing interest rates start from a low level, the negative relation between interest rate and debt-capital-ratio may be dampened or even be reversed. 
In our model, the relation between the interest rate and the equilibrium debt-capital-ratio, therefore, does not only depend on the parameters of the savings and the investment function, as in Lavoie (1995), but also on initial conditions, i.e. on the debt-capital-ratio in the initial equilibrium in the case of a stable long run equilibrium and on the level from which interest rates start to change when the mark-up is interest-elastic. These path-dependence features are absent from Lavoie's 'Minsky-Steindl-model'.

\section{Model behaviour when interest rates change: a simple case}

From our analysis so far it has become clear that the short run and long run effects of interest rate policies in our model may depend on the rentiers' propensity to save, the elasticity of investment with respect to debt and the interest rate, the responsiveness of investment to capacity utilisation and to unit labour costs, interest rate elasticity of the mark-up, and on initial values of the interest rate and the equilibrium debt-capital-ratio. This is summarised in equations (23)-(26) which display the long run effects of interest rate variations on the endogenous variables of the model:

$$
\begin{aligned}
& \frac{\partial \lambda}{\partial i}=\frac{s_{Z}\left(\frac{h}{v}-\beta\right)-\lambda\left[\beta\left(1-s_{Z}\right)-\theta \frac{h}{v}\right]+\frac{\partial h}{\partial i} \frac{1}{v}\left[i\left(s_{Z}+\theta \lambda\right)-\alpha-2 \tau h\right]}{i\left[\beta\left(1-s_{Z}\right)-\theta \frac{h}{v}\right]} \\
& \frac{\partial u}{\partial i}=\frac{\left(\lambda+i \frac{\partial \lambda}{\partial i}\right)\left(1-s_{Z}-\theta\right)+\frac{\partial h}{\partial i}\left(\tau-\frac{u}{v}\right)}{\frac{h}{v}-\beta}, \\
& \frac{\partial g}{\partial i}=\frac{\left(\lambda+i \frac{\partial \lambda}{\partial i}\right)\left[\beta\left(1-s_{Z}\right)-\theta \frac{h}{v}\right]+\frac{\partial h}{\partial i} \frac{1}{v}(\tau h-\beta u)}{\frac{h}{v}-\beta}, \\
& \frac{\partial r}{\partial i}=\frac{\frac{h}{v}\left(\lambda+i \frac{\partial \lambda}{\partial i}\right)\left(1-s_{Z}-\theta\right)+\frac{\partial h}{\partial i} \frac{1}{v}(\tau h-\beta u)}{\frac{h}{v}-\beta} .
\end{aligned}
$$

In what follows, we will trace the short and long run effects of changing interest rates through the model. Only stable goods market equilibria will be considered, but potential long run instability in the debt-capital-ratio is taken into account. For the sake of simplicity, our 
analysis of the effects on real variables is confined to the accumulation rate, and only the case of an interest-inelastic mark-up is explicitly discussed. For the other variables and for the case of an interest-elastic mark-up the interested reader is referred to the modifications and complications discussed above when deriving the relations between the monetary and financial variables, on the one hand, and the real variables of the system, on the other hand. The chosen simplifications make our results directly comparable to those derived by Lavoie (1995). They have the additional advantage that the model behaviour following interest rate variations only depends on three parameters, the rentiers' propensity to save $\left(\mathrm{s}_{\mathrm{z}}\right)$, the investment elasticities with respect to capacity utilisation $(\beta)$ and with respect to debt and interest costs $(\theta)$, and on the initial equilibrium debt-capital-ratio (Table 2).

\begin{tabular}{|c|c|c|c|}
\hline \multirow{2}{*}{\multicolumn{2}{|c|}{+2}} & \multicolumn{2}{|c|}{$\beta\left(1-s_{z}\right)-\theta \frac{h}{v}$} \\
\hline & & + & - \\
\hline $\begin{array}{l}\text { 1. Interest rate and } \\
\text { equilibrium } \\
\text { accumulation rate } \\
\text { in the short run }\end{array}$ & $\begin{array}{l}\frac{\partial g}{\partial i}, \lambda \text { constant, } \\
\text { equation }(15)\end{array}$ & + & - \\
\hline $\begin{array}{l}\text { 2. Interest rate and } \\
\text { equilibrium debt- } \\
\text { capital-ratio }\end{array}$ & $\begin{array}{l}\frac{\partial \lambda}{\partial i}, \\
\text { equation }(23)\end{array}$ & $\begin{array}{l}-, \text { if } \lambda> \\
0, \text { if } \lambda=\frac{s_{Z}\left(\frac{h}{v}-\beta\right)}{\beta\left(1-s_{Z}\right)-\theta \frac{h}{v}} \\
+, \text { if } \lambda<\end{array}$ & - \\
\hline $\begin{array}{l}\text { 3. Debt-capital- } \\
\text { ratio and } \\
\text { accumulation rate }\end{array}$ & $\begin{array}{l}\frac{\partial g}{\partial \lambda}, \text { i constant, } \\
\text { equation (12) } \\
\text { and Appendix } C\end{array}$ & + & - \\
\hline $\begin{array}{l}\text { 4. Interest rate and } \\
\text { equilibrium } \\
\text { accumulation rate } \\
\text { in the long run }\end{array}$ & $\begin{array}{l}\frac{\partial \mathrm{g}}{\partial \mathrm{i}}, \lambda \text { variable, } \\
\text { equation }(25)\end{array}$ & + & + \\
\hline $\begin{array}{l}\text { 5. Stability of long } \\
\text { run equilibrium } \\
\text { debt-capital-ratio }\end{array}$ & $\begin{array}{l}\frac{\partial \hat{\lambda}}{\partial \lambda}, \text { i constant, } \\
\text { equation }(21)\end{array}$ & $\begin{array}{c}- \\
\text { (stable) }\end{array}$ & $\begin{array}{c}+ \\
+ \\
\text { (unstable) }\end{array}$ \\
\hline
\end{tabular}

If $\beta\left(1-s_{Z}\right)-\theta \frac{h}{v}>0$, the long run equilibrium debt-capital-ratio will be stable. This requires that the rentiers' propensity to save is rather low and that investment is very responsive to capacity utilisation but very inelastic with respect to interest payments and debt. These conditions imply, on the one hand, an equal distribution of financial wealth across the 
economy. Assuming that the propensity to consume declines with rising income, a more equal distribution of financial wealth - and hence yields from financial wealth - will amount to a lower average propensity to save. On the other hand, a stable long run equilibrium implies stable conditions of finance for firms, so that in the face of variations in the interest rate or in the debt-capital-ratio creditors do not change their willingness to long term finance and debtors do not change their willingness to invest very much. If this is the case, the "principle of increasing risk' will only have little effect on investment. Decisions to invest are rather determined by sales expectations of firms than by the risks associated with increasing debt finance. We may expect that these conditions rather prevail in a bank-based finance system than in a capital-market based system. Bank-based systems are characterised by long-term relations between firms and creditors which are more stable than the short-term relations dominating in capital-market based systems (Grabel (1997)). Conditions for a stable long run equilibrium can also be assumed to prevail in periods of rapid and stable capital accumulation with stable sales expectations rather than in periods of stagnation with uncertain sales and profit expectations.

When the interest rate rises in a constellation with a long run stable debt-capital-ratio, in the short run, with a constant debt-capital-ratio, the rate of capital accumulation will increase. In the long run, the debt-capital-ratio will vary as well with the direction of variation depending on the initial debt-capital-ratio: Starting from a high ratio exceeding the benchmark derived above will lead to a falling equilibrium debt-capital-ratio, starting from a ratio below the benchmark will make the equilibrium debt-capital-ratio increase. The rate of accumulation in the long run stable constellation moves in the same direction as the debt-capital-ratio (Appendix C). However, taking the direct and indirect - via changing debt-capital-ratioseffects of changing interest rates into account, the equilibrium rate of capital accumulation will also rise in the long run (Appendix A). ${ }^{14}$

If $\beta\left(1-s_{z}\right)-\theta \frac{h}{v}<0$, the long run equilibrium will be unstable. This constellation requires a high rentiers' propensity to save, a low elasticity of investment with respect to capacity utilisation and an elastic responsiveness to changes in the interest rate or in the debt-capitalratio. These conditions will be given, if financial wealth and the yields from financial assets are unequally distributed across the economy and if fragile relations between the financial

\footnotetext{
${ }^{14}$ This is a result that also follows in Lavoie's (1995) paper but there it is not explicitly mentioned.
} 
sector and non-financial business dominate. Variations in interest rates then have significant effects on the willingness to finance and the willingness to invest. The "principle of increasing risk' has a dominant effect on investment whereas changes in capacity utilisation are of minor importance. We may expect these conditions to prevail in capital market based finance systems (Grabel (1997)). Prolonged periods of economic stagnation with uncertain sales and profit expectations should also be conducive to this constellation.

If interest rates increase in a parameter constellation yielding a long run unstable debt-capitalratio, in the short run, with a constant debt-capital-ratio, capital accumulation will decrease. The long run variable debt-capital-ratio will also go down (Appendix B). A falling debtcapital-ratio should then have a stimulating effect on the equilibrium accumulation rate countervailing the short-run effect (Appendix C). In the long run, the equilibrium rate of capital accumulation will rise, also in the unstable case (Appendix B).

However, the interpretation of the effects of rising interest rates under the conditions of an unstable long run equilibrium has to take into account, that changing interest rates will trigger an unstable disequilibrium process so that the new equilibrium will not be reached. Starting from a long run equilibrium position, rising interest rates cause falling accumulation rates in the short run and a falling equilibrium debt-capital-ratio in the long run. Since the actual debtcapital-ratio now exceeds the new long run equilibrium ratio, instability of this equilibrium means cumulative deviation of the actual from the equilibrium debt-capital-ratio. Therefore, the actual debt-capital-ratio will increase and finally approach unity. This unstable disequilibrium process is hence characterised by falling accumulation rates and rising debtcapital-ratios, both triggered by an increasing interest rate. We get a macroeconomic 'paradox of debt': ${ }^{15}$ Because of increasing interest rates firms cut down investment in order to reduce debt-capital-ratios and interest payments. The macroeconomic effect of this individual behaviour, however, is such that the actual debt-capital-ratios and hence interest payments will increase, inducing firms to further cut down investment etc.. When interest rates fall, the cumulative disequilibrium process is in the opposite direction: Falling interest rates induce rising rates of capital accumulation and falling debt-capital-ratios. When the 'paradox of debt' prevails, Kalecki's 'principle of increasing risk', i.e. a co-movement of investment and

\footnotetext{
${ }^{15}$ On the ,paradox of debt' see, in particular, Steindl (1952, pp. 113-122), Dutt (1995) and Lavoie (1995).
} 
indebtedness finally setting a limit to accumulation, is irrelevant at the macroeconomic level, as was already noted by Kalecki (1937) himself. ${ }^{16}$

\section{Conclusions}

The introduction of monetary variables into post-Keynesian models of distribution and growth is an ongoing process. Recently, Lavoie (1995) has proposed a Kaleckian 'Minsky-Steindlmodel' of distribution and growth, incorporating the effects of debt and debt services on short and long run capital accumulation. This attempt should be extended because neither has the rate of capacity utilisation been endogenously determined, nor have the potential effects of interest rate variations on distribution between wages and gross profits explicitly been considered. In the present paper we have therefore augmented Lavoie's 'Minsky-Steindlmodel'. The analysis has been based on a model briefly outlined by Lavoie (1993) and further elaborated in Hein (1999). Into this model the effects of debt and debt payments have explicitly been introduced, in the short as well as in the long run, and have been compared to those in Lavoie's 'Minsky-Steindl-model'.

In the short run, with the debt-capital-ratio taken as a given constant, the effects of interest variations on the stable equilibrium rates of capacity utilisation, capital accumulation and profit in our model depend on the interest rate elasticity of the mark-up, on the rentiers' savings propensity and on the elasticities of investment with respect to debt or debt services, on the one hand, and with respect to capacity utilisation, on the other. Depending on the values of these parameters, the effects of interest rate variations on the real equilibrium may be either negative throughout ('normal case'), mixed or even positive throughout ('puzzling case') with a low rentiers' savings propensity, a low debt services elasticity of investment and a high responsiveness of investment with respect to capacity utilisation being conducive to a positive effect of rising interest rates on capacity utilisation, capital accumulation and the profit rate. In the case of an interest-inelastic mark-up, the degree of indebtedness does not affect the direction of influence interest rate variations have on the real equilibrium. In the case of an interest-elastic mark-up, however, the degree of indebtedness may have an impact on the direction into which interest rate policies push the economy. From this it follows, that,

\footnotetext{
${ }^{16}$ This ,paradox of debt' also invalidates the macroeconomic relevance of Minsky's (1975) 'financial instability hypothesis' relying on a co-movement of investment and debt finally leading to a breakdown in investment due to increasing financial fragility, and of those post-Keynesian views by Minsky (1986), Palley (1996), Rousseas, (1998) and Wray (1990) arguing for endogenously increasing interest rates because of increasing indebtedness when investment rises (for a critique see also Lavoie $(1995,1996)$ ).
} 
contrary to Lavoie (1995), the degree of indebtedness has already to be taken into account when analysing the short run effects of monetary policies.

In the long run, the debt-capital-ratio is an endogenously determined variable. As in Lavoie (1995), long run stability is associated with the a parameter constellation which yields a short run positive ('puzzling') relation between the interest rate and the equilibrium rates of capacity utilisation, capital accumulation and profit: a low rentiers' savings propensity and a low sensitivity of investment with respect to debt or interest payments and a high elasticity with respect to demand or capacity utilisation. We have associated this parameter constellation with equal distribution of financial wealth, long term stable relations between the financial sector and non-financial business given in bank-based financial systems, and with periods of rapid capital accumulation with stable sales and profit expectations. The parameter constellation yielding a short run negative ('normal') relation between the interest rate and the equilibrium real variables, however, is associated with long run instability: a high rentiers' savings propensity and a high sensitivity of investment with respect to debt or interest payments and a low elasticity with respect to demand or capacity utilisation. This parameter constellation is more likely with unequal distribution of financial wealth, unstable relations between the financial sector and non-financial business aimed at short term capital gains as in capital market based systems, and in periods of stagnation with uncertain sales and profit expectations.

In our model, the relation between the interest rate and the equilibrium debt-capital-ratio does not only depend on the parameters of the savings and the investment function, as in Lavoie (1995), i.e. on the rentiers' savings propensity, on the elasticities of investment with respect to capacity utilisation, unit labour costs and debt services, and on the interest elasticity of the mark-up. The effects of interest rate policies on the long run equilibrium debt-capital-ratio and on the equilibrium rates of capacity utilisation, capital accumulation and profit may also depend on initial conditions, i.e. on the debt-capital-ratio in the initial equilibrium and on the level from which interest rates start to change. These path-dependence features are absent from Lavoie's 'Minsky-Steindl'-model.

Illustrating the effects of interest rate variations in our model we have finally assumed the simple case of an interest-inelastic mark-up. For the short run 'puzzling'/long run stable equilibrium it has been shown, that the effects of an increasing interest rate on the equilibrium 
debt-capital-ratio depend on the initial value of this ratio, i.e. there is an increasing effect if the initial value is low and a decreasing effect if the initial value is high. The long run effect on equilibrium capital accumulation, however, is always positive. In the short run 'normal'/long run unstable equilibrium, rising interest rates cause falling equilibrium debtcapital-ratios but rising long run equilibrium rates of capital accumulation. Due to long run instability, however, the new equilibrium cannot be reached. Already the simple variant of our model is hence characterised by an unstable disequilibrium process yielding the "paradox of debt': Rising interest rates cause falling rates of capital accumulation and rising debt-equityratios - a result similar to Lavoie's (1995).

\section{References}

Amadeo E.J. (1986): 'Notes on capacity utilisation, distribution and accumulation', Contribution to Political Economy, 5, pp. 83-94.

Amadeo E.J. (1986a): 'The role of capacity utilization in long period analysis', Political Economy, 2, pp. 147-160.

Amadeo E.J. (1987): 'Expectations in a steady-state model of capacity utilization', Political Economy, 3, pp. 75-89.

Arestis P. (1996): 'Kaleckis's role in post Keynesian economics: an overview', in King J.E. (ed.): An Alternative Macroeconomic Theory: The Kaleckian Model and Post-Keynesian Economics, Kluiwer, Boston.

Bhaduri A., Marglin S. (1990): 'Unemployment and the real wage: the economic basis for contesting political ideologies', Cambridge Journal of Economics, 14, pp. 375-393.

Ciccarone G. (1998): 'Prices and distribution in a Sraffian credit economy', Review of Political Economy, 10, pp. 399-413.

Dutt A.K. (1984): 'Stagnation, income distribution and monopoly power', Cambridge Journal of Economics, 8, pp. 25-40.

Dutt A.K. (1987): 'Alternative closures again: A comment on 'growth, distribution and inflation', Cambridge Journal of Economics, 11, pp. 75-82.

Dutt A.K. (1989): 'Accumulation, distribution and inflation in a Marxian/post-Keynesian model with a rentier class', Review of Radical Political Economics, 21 (3), pp. 18-26.

Dutt A.K. (1992): 'Rentiers in post-Keynesian models', in Arestis P., Chick V. (eds.): Recent Developments in Post-Keynesian Economics, Edward Elgar, Aldershot.

Dutt A.K. (1995): 'Internal finance and monopoly power in capitalist economies: A reformulation of Steindl's growth model', Metroeconomica, 46, pp. 16-34.

Dutt A.K., Amadeo E.J. (1993): 'A post-Keynesian theory of growth, interest and money', in Baranzini M., Harcourt G. (eds.): The Dynamics of the Wealth of Nations, Macmillan, London.

Dymski G.A. (1996): 'Kalecki's monetary economics', in King J.E. (ed.): An Alternative Macroeconomic Theory: The Kaleckian Model and Post-Keynesian Economics, Kluiwer, Boston.

Fazzari S.M., Hubbard R.G., Petersen B.C. (1988): 'Financing constraints and corporate investment', Brooking Papers on Economic Activity, 1, pp. 141-195. 
Grabel I. (1997): 'Savings, investment and functional efficiency: a comparative examination of national financial complexes', in Pollin R. (ed.): The Macroeconomics of Saving, Finance, and Investment, University of Michigan Press, Ann Arbor.

Graziani A. (1989): 'The theory of the monetary circuit', Thames Papers in Political Economy, Spring.

Graziani A. (1994): 'Monetary circuits', in Arestis P., Sawyer M. (eds.): The Elgar Companion to Radical Political Economy, Edward Elgar, Aldershot.

Hein E. (1999): 'Interest rates, income shares and investment in a Kaleckian model', Political Economy. Review of Political Economy and Social Sciences, 5, pp. 5-22.

Hein E. (2004): Verteilung und Wachstum. Eine paradigmenorientierte Einführung unter besonderer Berücksichtigung der post-keynesianischen Theorie, Metropolis, Marburg.

Hein E. (2004a): 'Money, credit and the interest rate in Marx's economics. On the similarities of Marx's monetary analysis to post-Keynesian economics', International Papers in Political Economy, 11 (2), pp. 1-43.

Hein E. (2006): 'Money, interest and capital accumulation in Karl Marx's economics: a monetary interpretation and some similarities to the post-Keynesian approach', European Journal of the History of Economic Thought, 13, forthcoming.

Hein E., Ochsen C. (2003): 'Regimes of interest rates, income shares, savings, and investment: A Kaleckian model and empirical estimations for some advanced OECD-economies', Metroeconomica, 54, pp. 404-433.

Hubbard R.G. (1998): 'Capital-market-imperfections and investment', Journal of Economic Literature, 36, pp. 193-225.

Kaldor N. (1956): 'Alternative theories of distribution', The Review of Economic Studies, 23, pp. 83100.

Kaldor N. (1957): ‘A model of economic growth', The Economic Journal, 67, pp. 591-624.

Kaldor N. (1961): 'Capital accumulation and economic growth', in Lutz F.A., Hague D.C. (eds.): The Theory of Capital, Macmillan, London.

Kaldor N. (1970): 'The new monetarism', Lloyds Bank Review, 97, July, pp. 1-17.

Kaldor N. (1982): The Scourge of Monetarism, Oxford University Press, Oxford.

Kaldor N. (1985): 'How monetarism failed', Challenge, May/June, pp. 4-13.

Kalecki M. (1937): 'The principle of increasing risk', Economica, 4, pp. 440-447.

Kalecki M. (1954): Theory of Economic Dynamics, George Allen, London.

Keynes J.M. (1933): 'A monetary theory of production', in The Collected Writings of J.M. Keynes, Vol. XIII, Macmillan, London, 1987.

Kurz H.D. (1994): 'Growth and distribution', Review of Political Economy, 6, pp. 393-420.

Kurz H.D. (1995): 'The Keynesian project: Tom Asimakopulos and „the other point of view“", in Harcourt G.C., Roncaglia A., Rowley T. (eds.): Income and Employment in Theory and Practice. Essays in Memory of Athanasios Asimakopulos, St. Martin's Press, New York.

Lavoie M. (1984): 'The endogenous flow of credit and the post-Keynesian theory of money', Journal of Economic Issues, 18, pp. 771-797.

Lavoie M. (1992): Foundations of Post Keynesian Economic Analysis, Edward Elgar, Aldershot.

Lavoie M. (1993): 'A post-classical view of money, interest, growth and distribution', in Mongiovi G., Rühl C. (eds.): Macroeconomic Theory: Diversity and Convergence, Cambridge University Press, Cambridge.

Lavoie M. (1995): 'Interest rates in post-Keynesian models of growth and distribution', Metroeconomica, 46, pp. 146-177. 
Lavoie M. (1996): 'Horizontalism, structuralism, liquidity preference and the principle of increasing risk', Scottish Journal of Political Economy, 43, pp. 275-300.

Lavoie M. (1999): 'The credit-led supply of deposits and the demand for money: Kaldor's reflux mechanism as previously endorsed by Joan Robinson', Cambridge Journal of Economics, 23, pp. 103-113.

Lavoie M., Rodriguez G., Seccareccia M. (2004): 'Transformational growth, interest rates, and the golden rule', in Argyros G., Forstater M., Mongiovi G. (eds.): Growth, Distribution, and Effective Demand, M.E. Sharpe, Armonk, New York.

Marx K. (1967): Capital. A critique of Political Economy. Vol. III. The Process of Capitalist Production as a Whole, International Publishers, New York.

Minsky H.P. (1975): John Maynard Keynes, Macmillan, London.

Minsky H.P. (1986): Stabilizing an Unstable Economy, Yale University Press, New Haven.

Moore B.J. (1988): Horizontalists and Verticalists: The Macroeconomics of Credit Money, Cambridge University Press, Cambridge.

Moore B.J. (1989): 'The endogeneity of credit money', Review of Political Economy, 1, pp. 65-93.

Palley T.I. (1996): 'Accomodationism versus structuralism: time for an accommodation', Journal of Post Keynesian Economics, 18, pp. 585-594.

Panico C. (1985): 'Market forces and the relation between the rate of interest and profit', Contributions to Political Economy, 4, pp. 37-60.

Pasinetti L.L. (1974): Growth and Income Distribution, Cambridge University Press, Cambridge.

Pivetti M. (1985): 'On the monetary explanation of distribution', Political Economy, 1, pp. 73-103.

Pivetti M. (1987): 'Interest and profit in Smith, Ricardo and Marx', Political Economy, 3, pp. 63-74.

Pivetti M. (1991): An Essay on Money and Distribution, Macmillan, London.

Pivetti M. (2001): 'Money endogeneity and monetary non-neutrality: A Sraffian perspective', in Rochon L.-P., Vernengo M. (eds.): Credit, Interest Rates and the Open Economy. Essays in Horizontalism, Edward Elgar, Cheltenham.

Robinson J. (1962): Essays in the Theory of Economic Growth, Macmillan, London.

Rochon L.-P. (1999): Credit, Money and Production. An Alternative Post-Keynesian Approach, Edward Elgar, Cheltenham.

Rochon L.-P. (2000): ‘1939 - 1958: Was Kaldor an endogenist?’, Metroeconomica, 51, pp. 191-220.

Rochon L.-P. (2001): 'Cambridge's contribution to endogenous money: Robinson and Kahn on credit and money', Review of Political Economy, 12, pp. 287-307.

Rousseas, S. (1998): Post Keynesian Monetary Economics, 3rd. edition, Macmillan, London.

Rowthorn R. (1981): 'Demand, real wages and economic growth', Thames Papers in Political Economy, Autumn.

Sawyer M. (1985): The Economics of Michal Kalecki, M.E. Sharpe, Armonk, New York.

Sawyer M. (2001): 'Kalecki on money and finance', European Journal of the History of Economic Thought, 8, pp. 487-508.

Sawyer M. (2001a): 'Kalecki on imperfect competition, inflation and money', Cambridge Journal of Economics, 25, pp. 245-261.

Schiantarelli F. (1996): 'Financial constraints and investment: methodological issues and international evidence', Oxford Review of Economic Policy, 12, pp. 70-89.

Seccareccia M. (1996): 'Post Keynesian fundism and monetary circulation', in Deleplace G., Nell E. (eds.): Money in Motion, Macmillan, London.

Seccareccia M. (2003): 'Pricing, investment and the financing of production within the framework of the monetary circuit: some preliminary evidence', in Rochon L.-P., Rossi S. (eds.): Modern Theories of Money, Edward Elgar, Cheltenham. 
Sraffa P. (1960): Production of Commodities by Means of Commodities, Cambridge University Press, Cambridge.

Steindl J. (1952): Maturity and Stagnation in American Capitalism, 2nd. edition, Monthly Review Press, New York, London, 1976.

Taylor L. (1985): 'A stagnationist model of economic growth', Cambridge Journal of Economics, 9, pp. 383-403.

Vernengo M., Rochon L.-P. (2001): 'Kaldor and Robinson on money and growth', European Journal of the History of Economic Thought, 8, pp. 75-103.

Wray L.R. (1990): Money and Credit in Capitalist Economies: The Endogeneous Money Approach, Edward Elgar, Aldershot. 


\section{Appendix A: Effects of interest rate variations with an interest-inelastic mark-up:} stable long run equilibrium

Starting from equations

$$
\frac{\partial \lambda}{\partial i}=\frac{s_{z}\left(\frac{h}{v}-\beta\right)-\lambda\left[\beta\left(1-s_{z}\right)-\theta \frac{h}{v}\right]+\frac{\partial h}{\partial i} \frac{1}{v}\left[i\left(s_{z}+\theta \lambda\right)-\alpha-2 \tau h\right]}{i\left[\beta\left(1-s_{z}\right)-\theta \frac{h}{v}\right]}
$$

and

$$
\frac{\partial g}{\partial i}=\frac{\left(\lambda+i \frac{\partial \lambda}{\partial i}\right)\left[\beta\left(1-s_{z}\right)-\theta \frac{h}{v}\right]+\frac{\partial h}{\partial i} \frac{1}{v}(\tau h-\beta u)}{\frac{h}{v}-\beta}
$$

assuming a stable short run goods market equilibrium as well as a stable long run debt-capitalratio and an interest-inelastic mark-up, the signs of $\frac{\partial \lambda}{\partial \mathrm{i}}$ and $\frac{\partial \mathrm{g}}{\partial \mathrm{i}}$ have to be determined. An interest-inelastic mark-up, i.e. $\frac{\partial \mathrm{h}}{\partial \mathrm{i}}=0$, reduces (23) and (25) to:

$$
\frac{\partial \lambda}{\partial i}=\frac{s_{z}\left(\frac{h}{v}-\beta\right)-\lambda\left[\beta\left(1-s_{z}\right)-\theta \frac{h}{v}\right]}{i\left[\beta\left(1-s_{z}\right)-\theta \frac{h}{v}\right]}
$$

and

$$
\frac{\partial g}{\partial i}=\frac{\left(\lambda+i \frac{\partial \lambda}{\partial i}\right)\left[\beta\left(1-s_{z}\right)-\theta \frac{h}{v}\right]}{\frac{h}{v}-\beta}
$$

The assumptions with respect to stability imply $\frac{\mathrm{h}}{\mathrm{v}}-\beta>0$ and $\beta\left(1-\mathrm{s}_{\mathrm{Z}}\right)-\theta \frac{\mathrm{h}}{\mathrm{v}}>0$. Given these assumptions, the sign of $\frac{\partial \lambda}{\partial i}$ from equation (23') depends on the value of $\lambda$, because (23') can be rearranged:

$$
\frac{\partial \lambda}{\partial i}=\frac{1}{i}\left[\frac{s_{z}\left(\frac{h}{v}-\beta\right)}{\beta\left(1-s_{z}\right)-\theta \frac{h}{v}}-\lambda\right]
$$

From this it follows: 


$$
\begin{gathered}
\frac{\partial \lambda}{\partial i}<0, \text { if } \lambda>\frac{s_{z}\left(\frac{h}{v}-\beta\right)}{\beta\left(1-s_{z}\right)-\theta \frac{h}{v}}, \\
\frac{\partial \lambda}{\partial i}=0, \text { if } \lambda=\frac{s_{Z}\left(\frac{h}{v}-\beta\right)}{\beta\left(1-s_{z}\right)-\theta \frac{h}{v}}, \\
\frac{\partial \lambda}{\partial i}>0, \text { if } \lambda<\frac{s_{Z}\left(\frac{h}{v}-\beta\right)}{\beta\left(1-s_{z}\right)-\theta \frac{h}{v}} .
\end{gathered}
$$

Inserting (23') into (25') yields:

$$
\frac{\partial \mathrm{g}}{\partial \mathrm{i}}=\mathrm{s}_{\mathrm{Z}}>0 \text {. }
$$

In the stable long run, rising rates of interest always have a positive effect on the equilibrium rate of capital accumulation. The same result follows from equations (17) and (19) and the assumption that $\hat{\lambda}=0$ in long run equilibrium. Therefore, it also applies to the case of an interest-elastic mark-up.

\section{Appendix B: Effects of interest rate variations with an interest-inelastic mark-up:} unstable long run equilibrium

Starting from equations

$$
\frac{\partial \lambda}{\partial \mathrm{i}}=\frac{\mathrm{s}_{\mathrm{Z}}\left(\frac{\mathrm{h}}{\mathrm{v}}-\beta\right)-\lambda\left[\beta\left(1-\mathrm{s}_{\mathrm{Z}}\right)-\theta \frac{\mathrm{h}}{\mathrm{v}}\right]+\frac{\partial \mathrm{h}}{\partial \mathrm{i}} \frac{1}{\mathrm{v}}\left[\mathrm{i}\left(\mathrm{s}_{\mathrm{Z}}+\theta \lambda\right)-\alpha-2 \tau \mathrm{h}\right]}{\mathrm{i}\left[\beta\left(1-\mathrm{s}_{\mathrm{Z}}\right)-\theta \frac{\mathrm{h}}{\mathrm{v}}\right]}
$$

and

$$
\frac{\partial g}{\partial i}=\frac{\left(\lambda+i \frac{\partial \lambda}{\partial i}\right)\left[\beta\left(1-s_{z}\right)-\theta \frac{h}{v}\right]+\frac{\partial h}{\partial i} \frac{1}{v}(\tau h-\beta u)}{\frac{\mathrm{h}}{\mathrm{v}}-\beta}
$$

assuming a stable short run goods market equilibrium, but an unstable long run debt-capitalratio and an interest-inelastic mark-up, the signs of $\frac{\partial \lambda}{\partial \mathrm{i}}$ and $\frac{\partial \mathrm{g}}{\partial \mathrm{i}}$ have to be determined. An interest-inelastic mark-up, i.e. $\frac{\partial \mathrm{h}}{\partial \mathrm{i}}=0$, reduces (23) and (25) to: 


$$
\frac{\partial \lambda}{\partial i}=\frac{s_{Z}\left(\frac{h}{v}-\beta\right)-\lambda\left[\beta\left(1-s_{Z}\right)-\theta \frac{h}{v}\right]}{i\left[\beta\left(1-s_{Z}\right)-\theta \frac{h}{v}\right]}
$$

and

$$
\frac{\partial g}{\partial i}=\frac{\left(\lambda+i \frac{\partial \lambda}{\partial i}\right)\left[\beta\left(1-s_{z}\right)-\theta \frac{h}{v}\right]}{\frac{h}{v}-\beta}
$$

The assumptions with respect to stability imply $\frac{\mathrm{h}}{\mathrm{v}}-\beta>0$ and $\beta\left(1-\mathrm{s}_{\mathrm{Z}}\right)-\theta \frac{\mathrm{h}}{\mathrm{v}}<0$. Taking these assumption into account and rearranging equation (23') always yields:

$$
\frac{\partial \lambda}{\partial i}=\frac{1}{i}\left[\frac{s_{z}\left(\frac{h}{v}-\beta\right)}{\beta\left(1-s_{z}\right)-\theta \frac{h}{v}}-\lambda\right]<0 .
$$

Inserting (23'’) into (25') gives:

$$
\frac{\partial \mathrm{g}}{\partial \mathrm{i}}=\mathrm{s}_{\mathrm{Z}}>0
$$

Also in the unstable long run equilibrium, rising rates of interest always have a positive effect on the equilibrium rate of capital accumulation. Again, the same result follows from equations (17) and (19) and the assumption that $\hat{\lambda}=0$ in long run equilibrium. Therefore, here it also applies to the case of an interest-elastic mark-up.

\section{Appendix C: Feedback effects of changing debt-capital-ratios on the equilibrium rates}

\section{of capacity utilisation, capital accumulation and profit}

Starting from equations

$$
\begin{aligned}
\mathrm{u}^{*} & =\frac{\lambda \mathrm{i}\left(1-\mathrm{s}_{\mathrm{Z}}-\theta\right)+\alpha+\tau \mathrm{h}}{\frac{\mathrm{h}}{\mathrm{v}}-\beta}, \\
\mathrm{g}^{*} & =\frac{\lambda \mathrm{i}\left[\beta\left(1-\mathrm{s}_{\mathrm{Z}}\right)-\theta \frac{\mathrm{h}}{\mathrm{v}}\right]+\frac{\mathrm{h}}{\mathrm{v}}(\alpha+\tau \mathrm{h})}{\frac{\mathrm{h}}{\mathrm{v}}-\beta},
\end{aligned}
$$




$$
\mathrm{r}^{*}=\frac{\frac{\mathrm{h}}{\mathrm{v}}\left[\lambda \mathrm{i}\left(1-\mathrm{s}_{\mathrm{z}}-\theta\right)+\alpha+\tau \mathrm{h}\right]}{\frac{\mathrm{h}}{\mathrm{v}}-\beta},
$$

feedback effects of changing long run debt-capital-ratios on the equilibrium rates of capacity utilisation, capital accumulation and profit have to be determined. We assume that changing debt-capital-ratios, for the reasons given in the text, will have no direct feedback effects on the interest rate or on the mark-up. Variations in indebtedness will hence only affect the distribution of profits between retained earnings and rentiers' income. This will in turn affect rentiers' consumption demand and firms' investment. From equations (11) - (13) we get:

$$
\begin{aligned}
& \frac{\partial \mathrm{u}}{\partial \lambda}=\frac{\mathrm{i}\left(1-\mathrm{s}_{\mathrm{Z}}-\theta\right)}{\frac{\mathrm{h}}{\mathrm{v}}-\beta}, \\
& \frac{\partial \mathrm{g}}{\partial \lambda}=\frac{\mathrm{i}\left[\beta\left(1-\mathrm{s}_{\mathrm{Z}}\right)-\theta \frac{\mathrm{h}}{\mathrm{v}}\right]}{\frac{\mathrm{h}}{\mathrm{v}}-\beta}, \\
& \frac{\partial \mathrm{r}}{\partial \lambda}=\frac{\frac{\mathrm{h}}{\mathrm{v}} \mathrm{i}\left(1-\mathrm{s}_{\mathrm{Z}}-\theta\right)}{\frac{\mathrm{h}}{\mathrm{v}}-\beta} .
\end{aligned}
$$

If only stable equilibria are considered $\left(\frac{\mathrm{h}}{\mathrm{v}}-\beta>0\right)$ and a positive rate of interest is assumed, we get the conditions displayed in Table $\mathrm{C} 1$ :

\begin{tabular}{|l|}
\hline $\begin{array}{l}\text { Table C1: Responses of the profit share, the rate of capacity utilisation, the rate of } \\
\text { accumulation and the rate of profit to a variation in the debt-capital-ratio: } \\
\text { stable equilibria }\end{array}$ \\
\hline$\frac{\partial \mathrm{u}}{\partial \lambda}>0$, if : $1-\mathrm{s}_{\mathrm{Z}}-\theta>0$ \\
$\frac{\partial \mathrm{g}}{\partial \lambda}>0$, if $: \beta\left(1-\mathrm{s}_{\mathrm{Z}}\right)-\theta \frac{\mathrm{h}}{\mathrm{v}}>0$ \\
\hline$\frac{\partial \mathrm{r}}{\partial \lambda}>0$, if $: 1-\mathrm{s}_{\mathrm{Z}}-\theta>0$ \\
\hline
\end{tabular}

It comes with no surprise, that under the assumptions made changing debt-capital-ratios have the same effects as changing interest rates in the case of an interest-inelastic mark-up. Rising debt-capital-ratios are associated with increasing values for the real equilibrium variables, if a 
low rentiers' savings propensity and a low elasticity of investment with respect to debt services prevail. A high responsiveness of investment to capacity utilisation supports a positive relation between indebtedness and capital accumulation. However, if the rentiers' savings propensity is rather high and associated with a high elasticity of investment with respect to debt services, rising indebtedness will rather have a negative effect on the real variables. A low responsiveness of investment to demand reinforces this negative impact on capital accumulation. 


\section{Seit 2000 erschienene WSI-Diskussionspapiere}

78. Seifert, Hartmut: Competition, Flexibility and Working Hours, Januar 2000

79. Bahnmüller, Reinhard / Bispinck, Reinhard / Weiler, Anni: Tarifpolitik und Lohnbildung in Deutschland am Beispiel ausgewählter Wirtschaftszweige, Februar 2000

80. Seifert, Hartmut: New Approaches to Working Time Policy in Germany: The 28,8 Hour Working Week at Volkswagen Company, Februar 2000

81. Truger, Achim: Kritisches zu den Wohlfahrtsaussagen der neueren Steuertheorie, Februar 2000

82. Ebert, Daniela: Bestimmungsfaktoren der Beschäftigung in der Bundesrepublik. Eine empirische Analyse der Faktorsubstitutionshypothese unter Berücksichtigung einer Alternativhypothese, Februar 2000

83. Truger, Achim: Steuerreformen für mehr Beschäftigung?, Februar 2000

84. Bispinck, Reinhard / Schulten, Thorsten: Alliance for Jobs: Is Germany following the path of ,competitive corporatism“"?, April 2000

85. Klammer, Ute: Working women in the age of flexibilitiy - new diversities, new needs for social protection, April 2000

86. Ziegler, Astrid: Die Europäischen Strukturfonds $2000-2006-$ Zu den Einflussmöglichkeiten der Sozialpartner in der Bundesrepublik Deutschland, April 2000

87. Truger, Achim: Ökologische Steuerreformen in Europa - Wo steht Deutschland?, Juni 2000

88. Truger, Achim: Konstitutionelle Ökonomik, Staatsversagen und „Wissenschaftsversagen“, September 2000

89. Klammer, Ute: Old problems - new solutions? - Working mothers between social policies and social practices - October 2000

90. Pelz, Thomas / Ziegler, Astrid: Synopse aktueller Untersuchungen zur Wirtschaftsentwicklung in den neuen Bundesländern, Dezember 2000

91. Schulte, Christiane / Ziegler, Astrid: Wettbewerbsmodelle in der deutschen Wirtschaftsund Strukturpolitik - ein neuer Fördertyp, Dezember 2000

92. Schulten, Thorsten: Solidarische Lohnpolitik in Europa - Ansätze und Perspektiven einer Europäisierung gewerkschaftlicher Lohnpolitik, März 2001

93. Sitte, Ralf: Zwischen Konzeption und Obstruktion - eine Betrachtung zum K(r)ampf um die Ökosteuer, April 2001 
94. Trautwein-Kalms, Gudrun/Viedenz, Jürgen: Dienstleistungsarbeit und Interessenvertretung, Sonderauswertung der WSI-Betriebsräte-Befragung 2000 für den privaten Dienstleistungsbereich, Mai 2001

95. Hein, Eckhard: Institutions and Macroeconomic Performance: Central Bank Independence, Labour Market Institutions and the Perspectives for Inflation and Employment in the European Monetary Union, June 2001

96. Ziegler, Astrid/Breuer, Tanja: Mehr Beschäftigung durch Europa? Umsetzung der europäischen Beschäftigungsstrategie in Ostdeutschland, August 2001

97. Behrens, Martin/Fichter, Michael/Frege, Carola M.: Unions in Germany Searching to Regain the Initiative - Project Reportfor the Hans-Böckler-Stiftung Projekt Nr. 2000-250-2, August 2001

98. Truger, Achim: Fiskalpolitik in der Europäischen Wirtschafts- und Währungsunion, September 2001

99. Bieling, Hans-Jürgen/Schulten, Thorsten: Competitive Restructuring and Industrial Relations within the European Union: Corporatist Involvement and Beyond?, November 2001

100. Bartsch, Klaus/Hein, Eckhard/Truger, Achim: Zur Interdependenz von Geld- und Lohnpolitik: Makroökonometrische Ex-post und Ex-ante Simulationen verschiedener Szenarien für die Bundesrepublik Deutschland, November 2001

101. Schulten, Thorsten: Europeanisation of Collective Bargaining - An Overview on Trade Union Initiatives for a Transnational Coordination of Collective Bargaining Policy, Mai 2001

102. Hein, Eckhard: Money, Interest, and Capital Accumulation in Karl Marx's Economics: A Monetary Interpretation, Juni 2002

103. Hein, Eckhard: Monetary Policy and Wage Bargaining in the EMU: Restrictive ECB policies, high unemployment, nominal wage restraint and rising inflation, Juni 2002

104. Ziegler, Astrid: Technologiepolitik in Nordrhein-Westfalen, September 2002

105. Berger, Christiane: Technologie- und Innovationspolitikin Bayern, September 2002

106. Riedel, Jürgen: Technologie- und Innovationspolitik in Sachsen, September 2002

107. Hein, Eckhard/ Truger, Achim: European Monetary Union: Nominal Convergence, Real Divergence and Slow Growth?, September 2002

108. Bartsch, Klaus: Das makroökonometrische Deutschlandmodell LAPROSIM QD 8.3 E. Eine Übersicht über zentrale Gleichungsspezifikationen und Grundzüge des Modellverhaltens, November 2002

109. Trautwein-Kalms, Gudrun (Redaktion): Arbeits- und Leistungsbedingungen im ITBereich, Fachtagung am 7. März 2002 in Bonn im Rahmen des BMBF-Projekts: DienstLeistung(s)-Arbeit, Tagungsdokumentation, Januar 2003 
110. Sitte, Ralf: Soziale Sicherung unter Rot-Grün - Zur Entwicklung von Sozialpolitik und Sozialbudget seit 1998, Januar 2003

111. Josten, Stefan Dietrich/ Truger Achim: The Political Economy of Growth and Distribution. A Theoretical Critique, März 2003

112. Ahlers, Elke: Arbeitsbedingungen, Leistungsdruck, Gesundheit am Arbeitsplatz März 2003

113. Hein, Eckhard: Die NAIRU - eine post-keynesianische Interpretation, März 2003

114. Ziegler, Astrid: Synopse wichtiger Positionen zur Reformdebatte der Europäischen Strukturpolitik nach 2006, April 2003

115. Tangian, Andranik: An Econometric decision model for equalizing regional unemployment in West and East Germany, July 2003

116. Ziegler, Astrid: Die europäische Strukturpolitik nach 2006 - Anforderungen an ein neues Konzept der europäischen Strukturfonds im Zeitraum 2007-2013, August 2003

117. Bäcker, Gerhard/ Koch Angelika: Mini- und Midi-Jobs als Niedrigeinkommensstrategie in der Arbeitsmarktpolitik. „Erfolgsstory“ oder Festschreibung des geschlechtsspezifisch segregierten Arbeitsmarktes?, August 2003

118. Truger, Achim: Germany's Poor Economic Performance in the Last Decade: It's the Macroeconomy, not Institutional Sclerosis, September 2003

119. Tangian, Andranik S.: Optimizing German regional policy-2004: A study based on empirical data from 1994 to 2001, December 2003

120. Truger, Achim: Verteilungs- und beschäftigungspolitische Risiken aktueller Steuerreformkonzepte: Eine Analyse mit Steuerbelastungsvergleichen für konkrete Haushaltstypen, Februar 2004

121. Niechoj, Torsten: Gewerkschaften und keynesianische Koordinierung in Europa. Chancen, Risiken und Umsetzungshürden, März 2004

122. Tangian, Andranik S.: Defining the flexicurity index in application to European countries, April 2004

123. Torsten Niechoj: Fünf Jahre Makroökonomischer Dialog - Was wurde aus den ursprünglichen Intentionen?, April 2004

124. Hein, Eckhard/ Schulten, Thorsten/ Truger, Achim: Wage trends and deflation risks in Germany and Europe, Juni 2004

125. Hein, Eckhard/ Truger, Achim: Macroeconomic co-ordination as an economic policy concept - opportunities and obstacles in the EMU, Juni 2004

126. Hein, Eckhard/ Niechoj, Torsten: Leitlinien für ein dauerhaftes Wachstum in der EU?, Juli 2004

127. Seifert, Hartmut: Arbeitszeitpolitischer Modellwechsel: Von der Normalarbeitszeit zu kontrollierter Flexibilität, Juli 2004 
128. Hein, Eckhard/ Schulten, Thorsten: Unemployment, Wages and Collective Bargaining in the European Union, September 2004.

129. Schulten, Thorsten: Foundations and Perspectives of Trade Union Wage Policy in Europe, August 2004

130. Seifert, Hartmut: Flexibility through working time accounts: reconciling economic efficiency and individual time requirements, September 2004

131. Tangian, Andranik S., Liberal and trade-Unionist concepts of flexicurity: Modelling in application to 16 European Countries, October 2004

132. Tangian, Andranik S., Constructing the composite indicator "Quality of work" from the third European survey on working conditions, November 2004

133. Hein, Eckhard, Interest rate, debt, distribution and capital accumulation in a postKaleckian model, Dezember 2004 